IZA DP No. 6552

What Happened to God's Time?

The Evolution of Secularism and Hours of Work in America, Evidence from Religious Holidays

Fernando A. Lozano

May 2012 


\title{
What Happened to God's Time? The Evolution of Secularism and Hours of Work in America, Evidence from Religious Holidays
}

\author{
Fernando A. Lozano \\ Pomona College \\ and IZA
}

Discussion Paper No. 6552

May 2012

IZA

P.O. Box 7240

53072 Bonn

Germany

Phone: +49-228-3894-0

Fax: +49-228-3894-180

E-mail: iza@iza.org

\begin{abstract}
Any opinions expressed here are those of the author(s) and not those of IZA. Research published in this series may include views on policy, but the institute itself takes no institutional policy positions.

The Institute for the Study of Labor (IZA) in Bonn is a local and virtual international research center and a place of communication between science, politics and business. IZA is an independent nonprofit organization supported by Deutsche Post Foundation. The center is associated with the University of Bonn and offers a stimulating research environment through its international network, workshops and conferences, data service, project support, research visits and doctoral program. IZA engages in (i) original and internationally competitive research in all fields of labor economics, (ii) development of policy concepts, and (iii) dissemination of research results and concepts to the interested public.
\end{abstract}

IZA Discussion Papers often represent preliminary work and are circulated to encourage discussion. Citation of such a paper should account for its provisional character. A revised version may be available directly from the author. 


\section{ABSTRACT \\ What Happened to God's Time? The Evolution of Secularism and Hours of Work in America, Evidence from Religious Holidays}

Are American workers less likely to observe a religious holiday now than they were 30 years ago? In this paper I use evidence from religious holidays to explore the evolution of market hours' flexibility and religious observance during the last thirty years. To do so, I take advantage of three different sources of exogenous variation: the first is the timing of the Current Population Survey, which allows me to observe data that is collected during different holidays in different years. The second is the timing of the religious holiday, as most are scheduled either with the lunar or the solar calendar. The third is the required observance of the holiday: in some holidays believers are called to abstain from work (Yom Kippur), in other holidays not (Tu b'Shevat), some holidays have been secularized (Saint Patrick's Day), and other holidays not (Good Friday). Additionally, I differentiate between any changes in hours of work during religious holidays across time and changes across cohorts. My results suggest that work schedules' flexibility has changed little during the sample period, yet less people are taking time off from work during Good Friday, while more people take time off from work during Yom Kippur, Rosh Hashanah, Mardigras and Saint Patrick's Day. These results are consistent with the increasing secularization of Christians in America, the Baal Teshuva movement among Jewish Americans, and the commercialization of Mardigras or Saint Patrick's Day. These results suggest a change in which holidays workers choose to observe.

JEL Classification: J22, Z12

Keywords: hours flexibility, religious holidays, secularization, work week

Corresponding author:

Fernando A. Lozano

Department of Economics

Pomona College

425 N. College Ave

Claremont, CA 91711

USA

E-mail: fernando.lozano@pomona.edu

\footnotetext{
* This research was supported in part by a grant from the Ford Foundation to the Research and Training Program on Poverty and Public Policy at the University of Michigan. I want to thank Colin P. Green and Dan Hamermesh for helpful comments and suggestions, as well as seminar participants at the University of Michigan, UC Santa Barbara and Pomona College. All errors remain mine.
} 


\section{Introduction}

Economists have noted that the American labor market has changed dramatically during the second half of the twentieth century, particularly with respect to the number of market hours worked or leisure hours. For example, Aguiar and Hurst (2007) show that while the number of leisure hours decreased among the highest paid Americans during the twentieth century, they actually increased among the lowest paid Americans. Similarly, Kuhn and Lozano (2009) show that highly educated males are working longer hours now that they did thirty years ago. Yet, in the context of longer work hours, we know very little about what has happened to workers' schedule flexibility during the last thirty years, especially any variation across time in a worker's ability to take time off from work. Conolly (2009) shows that workers tend to work longer hours on days when the weather is poor, and Skogman-Thoursie (2004) shows that people are more likely to report sick on Mondays following an important sporting event. That is, workers value the ability to reallocate the balance between work and leisure when utility of leisure is greater conditional on observing, consuming or attending a given event. In this paper, I present a novel methodology that measures what has happened to the flexibility of worker's schedule over the last thirty years using evidence from religious holidays. This measure is important for two reasons, first it informs whether these long term changes in hours of work are associated with short run variation in hours of work, but second it informs about the evolution of religious preferences and secularization in the United States. In addition, my empirical specification allows me to estimate whether any changes are due to time trends or to differences across cohorts. It is worth noting that religious and other holidays occur across all countries and different cultures, and understanding workers behavior across different days and holidays is of interest to economists and policy makers alike.

Schedule's flexibility, understood as a worker's short run deviations from his weekly hours of work, is important if a worker derives positive utility from events like a cultural festival, a religious holiday, or a sporting event; also a worker may need to abstain from work if a child gets sick, during a snow storm, or just when in need of a personal day. Some examples in the literature of the importance of short term variations in market hours of work are Alesina et at (2005) who argue that joint consumption across agents of a given event or holiday increases a person's utility, Dehejia et al (2007) who note that the observance of a religious holiday may be required as part of a group's identity, or Kalenkoski et al (2007) who explore parents' need to stay at home and take care of children if daycare or school is closed.

In this paper I estimate the flexibility of a worker's hours during religious holidays. Estimating a worker's schedule flexibility during religious holidays is not straight forward. For example, it can be argued that the timing of religious holidays is not random, and that people who plan these events will do so in days and weeks when demand for leisure is high (or demand for labor is low). For example, most sporting events 
are either during the weekends or late in the afternoon; similarly art exhibits and concerts are prevalent in the weekends. Even more, official national holidays intend to attenuate any disruption on the labor force, and are celebrated either on Mondays (Presidents day, Memorial day, MLK Jr day) or on Thursdays (Thanksgiving). ${ }^{1}$ Naive estimates of the change in hours of work during religious holidays may in fact reflect the non-random timing of the holiday, or even workers' preferences toward leisure. That is, for example, it may be that hours of work decrease during a religious holiday because either (i) the workers do value the event enough to change their hours, (ii) the timing of the holiday is during times when marginal product of work is relatively low, or (iii) those workers who report low hours during a religious holiday may very well have high utility from leisure and supply short hours even in the absence of such a day anyway ${ }^{2}$. In this paper I intend to answer the first question, have workers' work schedules and religious holidays observance changed during the last thirty years.

Using religious holidays to understand the evolution of schedule flexibility has the advantage of providing three exogenous sources of variation. The first source of variation is the timing in the survey of the data. For example, the Bureau of Labor Statistics collects data for the Current Population Survey (CPS, hereafter) every month during the week that includes the 19th day of each month, and the questions asked in the survey refer to the reference week which includes the 12 th day of each month. Thanks to this design, when a religious holiday rotates across the Gregorian calendar, sometimes its celebration falls in the weekend (with little expected change on weekly hours of work) and sometimes on a weekday (where we would predict a change on hours of work if workers value celebrating the holiday). The second source of variation has to do with the timing of the religious holiday, as most holidays are determined by either the lunar or the solar calendar. Thanks to this variation, the holiday will fall on the reference week of the CPS in some years, and it will not fall on the reference week in the CPS in other years. Furthermore, some holidays will fall on different months across different years. This allows me to compare hours of work during the same calendar day, but in different years - some years with a holiday and some without - these comparisons are either for the same worker or for two demographically equivalent workers. The final source of variation has to do with the nature of the holiday: there are holidays where the believer is called to abstain from work, there are holidays where the believer is not called to abstain from work. For example, empirically one would expect that the decrease of hours worked due to Yom Kippur would be greater than any decrease of hours during Tu b'Shevat, as the former holiday is a day where jewish workers are called to abstain from work

\footnotetext{
${ }^{1}$ Indeed, the Bureau of Labor Statistics and the Census are aware of the changes in labor supply during these days and avoid conducting any surveys during these days.

${ }^{2}$ Another possibility is that workers will reallocate their hours of work in the presence of religious holidays, that is work longer hours before or after a holiday to compensate for work lost during the holiday. This would be a concern if this reallocation of labor occurs across weeks, but not within weeks as my unit of measure is the workweek.
} 
for prayer and reflection, while no change in work hours is suggested during the latter Arbor Day. Thanks to these three sources of variation, I can distinguish between changes in workers' schedules during religious holidays, and not due to any labor market trends, year effects, nor spurious changes in preferences. Further, because of the availability of the data one can infer changes in workers' valuation of these holidays across long periods of time. As a matter of fact, in the application to religious holidays using the CPS, not only am I able to estimate changes in hours of work during these holidays, but I am able to understand the trend in these changes during the last thirty years, and I can compare whether any long term trend is due to a change across time or due to difference across cohorts. Importantly, a variation of this methodology could be expanded to a series of different events, such as: national holidays, sporting events, art exhibitions, music concerts, weather conditions, etc.

Empirically, there are two different results that draw unambiguous predictions about the evolution of schedule flexibility when using variation from religious holidays: the first outcome, a change in hours of work in the same direction during all religious holidays suggests that the driving force is a change of workers' ability to change their hours of work - for example more hours of work during all holidays regardless of origin or nature. The second possible outcome, which is a change in the hours of work during holidays only when a worker is expected to abstain from work, and no change during other holidays is suggestive of a change in the religious preferences, secularization or the intensity of such preferences. A different possibility yields ambiguous results, which would be different patterns across different holidays or no changes across time. The nature of the different holidays would help make labor market predictions in the existence of this later scenario. For example, if all jewish holidays change in the same direction and all christian holidays change in the same direction, then the researcher can imply changes in the observance of religious holidays across different denomination. This is the case with the results in this paper: my results suggest that reducing hours of work as observance of religious holidays has decreased little (increase in hours) relative to other workweeks during the last 30 years. But dividing the data across different holidays is supportive of a change in the intensity of preferences of religious holidays. My results show that American workers are less likely to take time off now than thirty years ago during Good Friday, and this is due to reinforcing changes across cohorts and changes across time. In contrast, my results suggest an increase in the frequency workers taking time off during the jewish holidays that require observance: Yom Kippur and Rosh Hashanah and these are due to changes across time, common to all cohorts. Note that this decrease in hours of work during Jewish Holidays is exclusive on holidays whose observance is mandated by religious authorities: Yom Kippur and Rosh Hashanah and not during Tu b'Shevat when workers are not asked to abstain from work. The result for Yom Kippur and Rosh Hashanah is supported in the wider literature with the Baal Teshuva or 
Kiruv ${ }^{3}$ among American jewish. Similarly, my results show more people taking time off from work during Mardigras and Saint Patrick's Day, yet these changes are mostly due to changes across cohorts. These results are important if these holidays have become secularized across all populations, and imply a rather festive observance instead than a devout one.

\title{
2 Religious Holidays
}

\author{
And ye shall do no manner of work in that same day; for it is a day of atonement, to make \\ atonement for you before the LORD your God. \\ Leviticus 28
}

Understanding a worker's change in hours of work due to a religious holiday is interesting on its own right. Religion plays an important role on shaping the life of many American workers. According to the Pew Forum for Religion and Public Life: 56 percent of all Americans claim that religion plays an important part of their life ${ }^{4}, 39$ percent of Americans report that they attend a religious service once a week, and 58 percent of Americans claim that they pray at least once a week. In contrast to Europeans whose religiosity has decreased during the last years (Berman et al, 2007), the proportion of Americans who report participating in organized religion has kept mostly constant ${ }^{5}$ (Iannaccone, 1998). While this literature relies on self reported-measures of religiosity, such as self reported attendance or beliefs, in this paper I use a "revealed preference" approach as a measure of religiosity with changes in hours of work due to religious holidays. That is, this work is the first one to use market outcomes to study the prevalence of religion and secularization ${ }^{6}$ in the United States. Further, little is known of the relationship between religious observance and labor market hours. For example, the above quote from the book of Letvicus indicates to Jewish workers that they must not work during the day of Yom Kippur, but to what extent do these workers abstain from work due to the observance of the holiday and not to labor-leisure preferences? Has this relationship changed across time. Understanding religious observance is important, as it has been associated with economic growth and better labor market outcomes (for example, see Freeman, 1993, Gruber, 2005 or Clingingsmith et al, 2009).

To understand the evolution of religiosity and labor markets, I test for two different hypotheses that explain any changes in a worker's decision to supply less hours of work during a religious holiday: whether

\footnotetext{
${ }^{3}$ Baal Teshuva means "master of return" in hebrew and refers to previously secularized jews who return to live according to Jewish Law.

${ }^{4}$ http://www.pewforum.org/How-Religious-Is-Your-State-.aspx accessed Jan 14, 2012

${ }^{5}$ Perhaps with the exception of Catholics, whose attendance has decreased.

${ }^{6}$ Although one can think of many definitions of secularization (see Bar-El et al (2012)), here by secularization I mean the decrease of shorter workdays due to the observance of a religious holiday.
} 
changes are due to differences across cohorts, or whether changes are due to a secular trend common to all cohorts. Distinguishing between the above hypotheses is possible as I can track the hours of work of every cohort in the CPS ORG during the last thirty years, and a change in the hours of work due to cohort differences will show different life-hours profiles across workers born in different years. In addition, by comparing holidays of different nature - some that call for strict observance and work absenteeism, some which have been secularized, and some which remain exclusive to a religious denomination - I can test whether changes in hours of work are common to all or exclusive to some holidays. The former result is suggestive of a change in the schedule flexibility of american workers. In contrast, the latter is suggestive of either a change in religious preferences, or a change of the intensity of such preferences, without changes to the work schedule flexibility. Table 1 shows the timing of the religious holidays in this paper across 30 years of data. Note that I include some holidays where abstaining from work is required and holidays where abstaining from work is not required. Empirically, I compare three types of religious holidays: those whose believers are encouraged to abstain from work by their religious leaders: Yom Kippur, Good Friday, Rosh Hashanah or Eid-al-Adha; holidays whose believers are not encouraged to abstain from work: Tu b'Shevat or the first day of Ramadan; and holidays who have been secularized by society, regardless of religious background: Saint Patricks Day or Mardigras. Again, a change due to religious preferences will show different patterns for holidays mandated by religious authorities than for other holidays. In this case I expect changes in the hours of work during the holiday's week to be different when absenteeism is mandated than during other secularized holidays.

In this paper I use eight holidays that should satisfy four conditions: (1) It's timing should be determined independently from the labor market, should rotate across the Gregorian calendar and should occur sometimes during the CPS reference week; (2) there should be some variation in the nature of the holiday, where abstentionism from work should be observed in some of them and not in others; (3) the number of people that celebrate this holiday should be large enough to be able to make any statistical inference; and (4) the holiday should occur during the CPS reference week at least four times during the 30 years of data. As such, I select the following eight holidays in this paper: Good Friday, Saint Patrick's Day, Mardigras, Yom Kippur, Rosh Hashanah, Tu b'Shavot, the first day of Ramadan and Eid-al-Adha. The first three holidays are Christian in nature, yet Mardigras and Saint Patrick's day originally celebrate Catholic traditions that by now have been mostly secularized. While neither of these Christian holidays is considered a Day of Obligation by the Catholic Church, Good Friday has long been considered a day of prayer and fasting by all Christian traditions. ${ }^{7}$. Yom Kippur, Rosh Hashanah and Tu b'Shevat are all jewish holidays. Work is not permitted in Yom Kippur and Rosh Hashanah, the latter holiday usually lasts two days while Yom Kippur

\footnotetext{
${ }^{7}$ It is worth noting that often Good Friday overlaps with the Jewish celebration of Passover.
} 
only one. In contrast, there is no mandate to abstain from work during Tu b'Shevat that commemorates the New Year of trees. there are few traditions or obligations related with Tu b'Shevat and these mostly involve planting trees and eating fruit. The final two holidays correspond to muslim believers and they are the first day of Ramadaan and Eid-al-Adha. The only requirements to believers on the first day of Ramadan are to pray, fast and give to charity; there are no requirements to avoid work. In contrast during Eid-al-Adha, which occurs at the end of the Hajj and commemorates the sacrifice that Abraham gave to God, muslims are required to pray and visit family and friends during the day. At some point during the day, believers are required to sacrifice an animal and distribute its meat among friends, family and the poor. One thing to keep in mind with muslim holidays is that they start when the local imam sights the new moon, and thus there are some important spatial variations on when this holiday is celebrated although not relevant to this study as my period of observation is the complete CPS reference week and not any given day.

\section{Empirical Strategy}

To understand the causal relationship between a religious holiday and hours of work, I take advantage of the structure of the CPS. This survey is collected every month on the week that includes the 19th day of the month, and the reference week is the week that includes the 12th of each month. The sample in this survey is representative of the population in the United States, and each monthly survey is divided into eight nationally representative samples called rotations. Each household chosen to be in the sample, remains in the sample for eight surveys or rotations. When a household is sampled, this household will belong to the first rotation during its first survey or first month in the sample. In the next month, this household will be in the second rotation, and in the next two months the household will be in the third and fourth rotation respectively. Then, this household will be out of the sample for eight months, and then return to the sample in the fifth rotation (thirteenth month) a year after it was first surveyed. ${ }^{8}$ The fourteenth month after the household is first surveyed will be the sixth rotation, fifteenth month the seventh rotation and the sixteenth month the eight rotation. The Outgoing Rotations labor market supplement is collected during the fourth and eight rotations.

An example of how I take advantage of the CPS structure is shown in Table 2. A household whose first rotation was in July 2000 belongs to the sample labeled U in Table 2. Note that this sample is in the fourth rotation in October 2000 and Yom-Kippur occurred during the CPS reference week. This household's labor market information is collected at this time. This household, who returns to the survey in the fifth rotation

\footnotetext{
${ }^{8}$ Because this household is surveyed during the same month in consecutive years, the CPS will work here technically as a pseudo-panel
} 
in June of 2001, and it is in the eight rotation in October 2001. At this time the labor market information is collected again, yet there is no holiday during the reference week. Indeed, Yom Kippur occurred in September 2001. My empirical strategy consists of estimating changes in hours of work between October 2000 (with Yom-Kippur) and October 2001 (without Yom-Kippur). Note that the identifying assumption is that unobserved characteristic that may lead a household or not to change their hours of work at any given time should be time invariant, and the only difference is the presence of a religious holiday during the CPS reference week in October 2000.

Thus my first model estimates the following ordinary least squares regression:

$$
G a p_{i t}=\theta H_{i t}+x_{i t}^{\prime} \beta+\gamma_{j}+\lambda_{k}+\phi_{s}+\epsilon_{i t}
$$

with $H_{i t}=1\{i$ is surveyed in a reference week with a religious holiday $\}$. Equation (1) includes a battery of demographic characteristics in vector $x_{i t}^{\prime}$ such as: age, age squared, education, marital status, gender, hispanic, and black indicators. In addition, to control for differences across months during the year I include month fixed effects $\lambda_{k}$, and to control for year-occupation trends I include year-occupation fixed effects $\gamma_{j}$. Finally, I also include state of residence fixed effects $\phi_{s}$. If workers do reduce their hours of work during the reference week with a religious holiday, the we expect that $\hat{\theta}<0$.

I construct my response variable Gap $_{i t}$ by subtracting the worker's hours of work in the reference week from her usual hours ${ }^{9}:$ Gap $_{i t}=$ Actual $_{i t}-U s u a l_{i t} \times 60$ where $i$ indexes the observation and $t$ the reference week in a given month and year. In the Outgoing Rotations supplement the CPS asks two questions that together will constitute my main unit of observation: usual hours of work in your main job and last week's hours of work in your main job. Note that Gap $_{i t}=0$ if hours last week do not differ from usual week's hours. In contrast, Gap it $_{<0}$ shows that during week $t$ the hours of work of this worker were shorter than in the usual week. In order for the variable Gap $_{i t}$ to validly identify any deviations in hours of work during the reference week it must be that both last week hours and usual hours refer to the same metric, and the

\footnotetext{
${ }^{9}$ And multiplying by 60 to interpret it in minutes.
} 
only thing that changes is the time reference the question refers to. ${ }^{10}$

In addition, because I have a very large number of observations which might be clustered around different periods of time, I am concerned that I may be underestimating my standard errors (Moulton, 1990). To reduce the probability of Type I statistical error, I estimate Equation 1 clustering at the Primary Sample Unit. Alternatively, I collapse the data into state-month-year averages and estimate a version of equation (1) that excludes the demographic characteristics in the vector $x$ but still uses state, month and year fixed effects:

$$
\operatorname{Gap}_{s t}=\theta H_{s j k}+x_{s t}^{\prime} \beta+v_{j}+\lambda_{k}+\phi_{s}+\epsilon_{s j k}
$$

where the subscripts $j$ represents year, $s$ represents state and $k$ months. In total this specification has 18,156 observations (356 months $\times 50$ states) ${ }^{11}$

Although the estimate of $\theta$ in equation (1) above contrasts hours of work between reference weeks with and without religious holidays, this estimate does not address whether the magnitude of $\theta$ has changed over time. Next, I can take advantage of the variation in time that 30 years of CPS data gives and test for the heterogeneity of $\theta$. To do so, I estimate the following ordinary least square regression:

$$
\text { Gap }_{i t}=\theta^{80} H_{i t} \times 1980+\theta^{90} H_{i t} \times 1990+\theta^{00} H_{i t} \times 2000+x_{i t}^{\prime} \beta+\gamma_{j}+\lambda_{k}+\phi_{s}+\epsilon_{i t}
$$

where 1990 and 2000 are dummy variables indicating whether an observation was surveyed between 1980 to 1999, and 2000 to 2008 respectively. $H_{i t} \times 1980, H_{i t} \times 1990$ and $H_{i t} \times 2000$ are interaction terms between reference weeks with a religious holiday and whether the observation was surveyed in the 1980's (1979-1989), 1990's (1990-1999) or 2000's (2000-2008). Importantly, $\theta^{1980} \neq \theta^{1990}-\eta^{1990} \neq \theta^{2000}-\eta^{2000}$ suggests that the change in hours of work during a religious holiday by american workers differs across thirty years of data. In particular, secularization implies $\theta^{1980}<\theta^{1990}-<\theta^{2000}$.

Estimates of equation (3) will produce biased estimates of $\theta^{Y Y Y Y}$ if the effect across years is correlated

${ }^{10}$ The CPS questionnaire indicates that for last week's hours the interviewer asks:

Last Week HRACT1: ((LAST WEEK/THE WEEK BEFORE LAST)/So, for (LAST WEEK/THE WEEK BEFORE LAST)), how many hours did (you/he/she) ACTUALLY work at (your/his/her) (job?/MAIN job?)

and the usual week question the interviewer asks:

Usual HRUSL1: How many hours per week (do/does) (name/you)USUALLY work at (your/his/her) (job?/main job? By main job we mean) (the one at which (you/he/she) usually) ((work/works) the most hours.)

it seems reasonable that these two questions do refer to the same metric, and the only thing that varies is the time period the question refers to: one is last week and the other one is the usual week.

${ }^{11}$ I drop from the data observations surveyed in September 1981, September 1987, September 1992, September 1998 and September 2008 as Labor day fell within the CPS reference week. 
with differences across cohorts. For example, if younger cohorts are less likely to observe a holiday, then a monotonic decrease in the magnitude of $\theta^{Y Y Y Y}$ would suggest that workers are less likely to observe a holiday in the later part of the sample, rather than capture differences across cohorts where the older workers have not change their observance and neither have the younger workers. To differentiate if any changes in a worker's schedule flexibility is across cohorts or within cohorts, I follow Borjas $(1985,1995)$ to estimate the following equation:

$$
\begin{aligned}
\text { Gap }_{i t} & =\sum_{k=1}^{3}\left(\theta_{k} H_{i t} \times C k_{i t}\right)+\sum_{T=80,90,00} \sum_{k=1}^{3}\left(\psi_{k} C k_{i t} \times T_{i t}\right)+ \\
& \theta^{1980} H_{i t} \times 1980+\eta^{1990} 1990_{i t}+\theta^{1990} H_{i t} \times 1990_{i t}+\eta^{2000} 2000_{i t}+\theta^{2000} H_{i t} \times 2000_{i t}+x_{i t}^{\prime} \beta+\epsilon_{i t}
\end{aligned}
$$

where $C k$ for $k=1,2,3$ represent different cohorts of workers born in the following intervals:

$$
\begin{aligned}
& C 1=1 \cdot\{i \text { born before } 1950\} \\
& C 2=1 \cdot\{i \text { born } 1950 \& 1960\} \\
& C 3=1 \cdot\{i \text { born } 1961 \text { or later }\}
\end{aligned}
$$

As in equation (2) and (1), $\theta_{k}$ represents the change in hours of work for cohort $k$ in during a religious holiday. Using this methodology I am able to compare not only changes in hours of work, but to understand schedule flexibility across time, and across cohorts. Importantly, the underlying assumption in equation is that time off from work during religious holidays varies independently across cohorts and across time. Therefore $\theta^{Y Y Y Y}$ indicates the variation of hours across time independent of cohort composition, and $\theta_{k}$ indicates the variation of hours across cohort, net of time effects.

\section{Data}

In this paper I use the 1979-2008 collection of the CPS ORG. These data includes all respondents in the fourth and eight rotations of the CPS, when a special labor market survey is administered to all reference persons aged sixteen and above. My sample includes all not self-employed workers, currently employed fulltime workers ${ }^{12}$, aged 24-65. In this paper I include both men and women, yet the results change little if I separate them. In addition, because I want to explore schedule flexibility net of missing days of work due to illness, vacation or bad weather, I drop all observations who reported missing work in the reference week due

\footnotetext{
${ }^{12}$ Usual hours greater than 29
} 
to these causes. I do one further exclusions to the sample, I drop all observations with hourly incomes of less than two hours. This may be problematic as suggested by Bollinger and Chendra (2005) yet the results of the paper are robust to the omission of this exclusion. Finally, I drop from the sample all observations in the September 1981, September 1987, September 1992, September 1998 and September 2008 surveys because Labor Day coincides with the CPS reference week.

Figure 1 shows the average Gap $_{i t}$ for all workers between 1979 to 2008. The solid line represent all time periods when the reference week in the CPS did not include a religious holiday. The trend in this metric is to decrease somewhat during the early part of the sample, and then it fluctuates close to zero. ${ }^{13}$ The eight religious holidays are also represented in this figure - with standard errors. As can be seen, and as in the secular trend above, some holidays also reflect a drop in the average of $G_{a p}$, yet the decrease is greatest among Hajj, Good Friday, and to a lesser extent Ramadan. The average of Gapit during other holidays remains mostly constant similarly to the trend of weeks without holidays. Although somewhat informative, this figure represents an incomplete view and these estimates are unconditional on month of the survey as well as the respondents' demographic characteristics. For example, Ramadan in 1983 occurs in June when schools and some jobs are likely to be on vacations, in contrast with other years when Ramadan occurs in September, October or November. Table 2 shows those months in the sample when the CPS reference week occurs during a religious holiday. As can be seen, there is significant variation in the timing of these eight holidays, not only with regards of whether they are in the CPS reference week, but also with regards to the month in which they occur.

\section{Results}

Table 3 presents estimates of equation (1). The first column on the top panel presents estimates of equation (1) where $H_{i t}$ includes a dummy variable for any observation surveyed during a CPS survey that coincided with Good Friday. This estimate suggests that on average, when the observation is surveyed during a week that includes this holiday, work will decrease on average by 78 minutes compared to weeks without a holiday. The second column presents estimates for the change in hours during Yom Kippur, the third column estimates for Rosh Hashanah and the fourth column presents estimates when the reference week contains Tu b'Shevat. These estimates reflect two facts: there are smaller in magnitude than Good Friday, as these are average treatment effects over the population, and the Jewish population in America is smaller in size than

\footnotetext{
${ }^{13}$ The CPS was redesigned in 1995 to improve accuracy of the responses, and it is possible that a decrease in Gap $_{i t}$ is due to an improvement in the design of the survey (Author, 2006). While this is possible, it is worth noting that the trend around zero starts way before 1995 and likely reflect labor market dynamics and not design concerns by itself.
} 
the Christian population. In addition, these estimates show the different nature of these holidays: while jewish believers must abstain from work during Yom Kippur and Rosh Hashanah, not so from Tu b'Shevat. This is evidenced by the magnitude, sign and precision of the estimates: in reference weeks that coincide with Yom Kippur, american workers reduce their hours by 8 minutes and this estimate is statistically different to zero, in reference weeks with Rosh Hashanah the estimate is not statistically significant different from zero, and in contrast in reference weeks that include Tu b'Shevat the estimate is positive and statistically significant greater than zero ${ }^{14}$. A back of the envelop calculation may inform the magnitude of the change in hours of work during Yum Kippur: if a working day contains 480 minutes, and if we assume that the Jewish population is approximately 2\% (Pew Religion Life, YYYY)) then it must be that 8 minutes represents $1.7 \%$ of all minutes usually worked during a 40 hour work week $--\frac{8}{40 \times 60}$. The first column in the bottom panel presents estimates when the survey week coincides with the first week of Ramadan, and the second column presents estimates when the survey week coincides with the Eid-al-Adha, neither of these estimates is statistically significant different from zero. Finally, columns (3) and (4) in the bottom panel shows estimates of two holidays, that although Christian in nature, have become secularized and are celebrated widely: Saint Patrick's Day and Mardigras. The estimates show that American workers do tend to reduce their hours of work in survey weeks that coincide with Saint Patrick's Day with an estimate of 9 minutes of work less, yet for Mardigras there is no statistically significant change. Table 4 presents the estimates of equation (2) where the data is aggregated at the state-month-year level. Importantly, although the standard errors do increase slightly, even with the data collapsed at this level there is virtually no difference in both the magnitude and the precision of the estimates.

Table 5 presents the dynamics of hours of work during religious holidays during the thirty years of data. The first column in the top panel shows the estimate across time for changes in hours of work when Good Friday coincides with the CPS reference week. The first row shows the coefficient's estimate for holidays during the 1980's, the second row shows the coefficient's estimate for holidays during the 1990's, and the third row the coefficient's estimate for holidays during the 2000's. The results suggest a clear decreasing pattern in the amount workers change their hours of work during weeks with Good Friday: 102 minutes in the 1980's, 76 minutes in the 1990's, and 56 minutes in the 2000's. Importantly these estimates are statistically different to each other, suggesting that either American workers are less likely to observe good Friday by reducing their hours of work in recent years or that their preference for religious holidays has changed. The second column presents estimates for Yom Kippur. Opposite to the results from Good Friday, American

\footnotetext{
${ }^{14}$ At first it seems puzzling that the coefficient for Tu b'Shavet is statistically significant and positive. This is mostly because the Holiday falls in February, and in the absence of a religious holiday February is the month when workers are the most likely to abstain from work. Below I further explore this issue.
} 
workers are more likely to take time off when the reference week coincides with Yom Kippur in the later part of the sample. During the 1980's and 1990's there were no statistically significant change in the hours of work during Yom Kippur, yet during the 2000's the coefficient estimate becomes negative and statistically significant implying that American workers reduce their hours of work by almost 12 minutes during the week of Yom Kippur. Note that the coefficient for 1980 although negative, is measured imprecisely with high standard errors $(\mathrm{p}=0.12)$. Finally, also note that the coefficients for 1990 and 2000 are statistically different from each other. The third column represents the estimates for Rosh Hashanah. Here a similar pattern is observed: the estimates from 1980 and 1990 are zero, yet the estimate for 2000 is negative and statistically different to the other two coefficients. The fourth column represents when the reference week coincides with Tu b'Shevat and, as in Table 1, none of the coefficients is statistically smaller zero. Note that while the results for Good Friday suggests a secularization of American Christians, the coefficients for Yom Kippur and Rosh Hashanah suggests the opposite, that jewish believers are more likely to observe this holidays now than 30 years ago. This movement, where previously secularized jewish households return to observe the jewish law, is well known within judaism and is called Kiruv.

The bottom panel of Table 5 presents the estimates of equation (3) for Ramadan in the first column, EidAl-Adha in the second column, Saint Patrick's Day in the third column, and Mardigras in the fourth column. Again, as in Table 1, none of the estimates of Ramadan or Eid-Al-Adha are statistically significant different to zero. In contrast, during weeks when the reference week coincides with Saint Patrick's Day American workers are increasingly more likely to take time off. The estimate for the coefficient during the 1980's is not statistically different from zero, during the 1990's this estimate increases to 8 minutes per week yet still not statistically significant, and during the 2000's the magnitude of the coefficient increases to 12.45 minutes (the latter is statistically significant different from zero). Finally the coefficient for Mardigras is negative and statistically significant in 1980, and becomes zero afterwards. This pattern, mimics in much smaller scale, that of Good Friday and there are two possible explanations to it. First, that it shows an effect particular to Louisiana and Alabama, where Mardigras is a state holiday ${ }^{15}$. Alternatively, and more persuasive, is the fact that as Mardigras (Fat Tuesday) and Ash Wednesday occur during the same week, and the similarity to the Good Friday estimates is capturing a decrease in the observance of Ash Wednesday, rather than Mardigras. Note that the estimate for Saint Patrick's Day is supported by the fact that this holiday has been secularized in the United States, and many celebrate this day regardless of ancestry or religion. Finally, in addition to the jewish holidays of Yom Kippur and Rosh Hashanah these results contradict the hypothesis that suggests less flexibility in the workforce, and may rather be indicative of a change in the type of holidays American workers choose to "observe."

\footnotetext{
${ }^{15}$ A replication of equation 3, not reported here, without Louisiana and Alabama yield very similar results.
} 
There is the possibility that the results presented in Table 3, Table 4 or Table 5 are due to a spurius change or phenomena that is omitted to the researcher. To test for such possibility, I develop a falsification test or placebo experiment, that will allow me to test whether the results presented above are spurious or not. To do so, I generate a dummy variable for a placebo holiday: first I randomly choose a number to assign how many placebo holidays I will observe in the experiment, this number is bounded on the left side by 4 and on the right side by 7 . Then, I randomly assign a month-year combination to each one of these placebo holidays, in such a way that I end up with at least four and at most seven randomly occurring placebo holidays in the data ${ }^{16}$. Then I estimate equation (1) 1,000 times using these placebo estimates. The distribution of these Placebo estimates is shown in Figure 1. Note that the distribution is quite symmetric with a median $\hat{\theta_{50}}=0.54$ minutes and mean $\hat{\bar{\theta}}=0.46$ minutes. Importantly, and compared to the coefficient estimates in the previous sessions, note that ten percent of all coefficients are smaller than $\hat{\theta_{10}}=-8.58$ minutes and the smallest five percent of all coefficients is $\hat{\theta_{5}}=-12.23$ minutes. In this context, the estimates for Good Friday, Yom Kippur and Saint Patrick's Day in Table 1 are very unlikely to occur (with p values of $p=0.00$, $p=0.10$ and $p=0.08$ respectively).

A second robustness test involves estimating equation (1) and equation (3) for different subsamples. Table 6 shows the estimates of these equations where the estimates for Yom Kippur and Rosh Hashanah are computed only using New York and Florida (the two states with largest jewish population) as a sample, the estimates for Good Friday and Mardigras are computed using Louisiana and Alabama only, and the estimates for Saint Patrick's Day are computed for New York and Massachusetts only. The top panel shows the estimates for equation (1) and the results suggest that these changes in hours of work are larger in magnitude in these states, where the average worker in New York and Florida lowers his hours of work in weeks during Yom Kippur by 14 minutes ${ }^{17}$. The bottom panel presents estimates for equation (3) and in this case, the estimates for both Yom Kippur and Rosh Hashanah are not different to zero in 1980's or 1990's, but the magnitude of the estimate for 2000's jumps again to 24 minutes for Yom Kippur and 22 for Rosh Hashanah. The third and fourth column in Table 6 show estimates for Good Friday and Mardigras in Louisiana and Alabama only. The top panel shows the estimates for equation (1) and the bottom panel shows the estimates for equation (3). The estimates of $\theta$ with a sample of these two states increase in both Holidays, but most dramatically, and unsurprisingly, during Mardigras. This new estimate suggests that in reference week when Mardigras occur workers in these states reduce their hours of work by 80 minutes. The

\footnotetext{
${ }^{16}$ In here, I also drop all observations who were surveyed in a reference week that included an actual religious holiday.

${ }^{17}$ Again, a back of the envelope calculation suggests that the change in total hours of work will represent 0.03 percent of all working hours, this is close to the estimates of the jewish population in these states of $3 \%$ in Florida and $6 \%$ in New York
} 
bottom panel shows diverging trends between Good Friday and Mardigras: the amount of workers taking time off from work during Good Friday falls from 136 minutes in the 1980's to 18 minutes (not statistically different to zero) in the 2000's. In contrast, the estimate for Mardigras is 40 minutes less of work (with high standard errors) during the 1980's and the magnitude of these estimates increase to twice its size in the 2000's. These diverging trends supports the idea that hours flexibility during religious holidays has not changed in the last thirty years, instead workers in Louisiana and Alabama are more likely to work nowadays during Good Friday (evidence of secularization) and take time off during Mardigras (which has become secularized and commercialized). Finally, column 5 shows the estimates for equations (1) and (3) during Saint Patrick's Day restricting the sample to New York and Massachusetts (both states with a strong history of Irish migration), and surprisingly these estimates are not different to zero. Notice that this differs from the estimates in Tables 1,2 and 3 and possibly suggest that Saint Patrick's Day has little to do with its original Irish heritage and more with a secularized holiday celebrated by all. ${ }^{18}$

Table 7 presents estimates of equation (4) where controls for cohorts, and cohorts interacted with holidays are added. The top panel shows the complete sample for Yom Kippur, Rosh Hashanah, Good Friday, Mardigras and Saint Patrick's. The bottom panel presents estimates for the same Holiday's but for the same subsamples as in Table 6. For the Jewish Holidays of Yom Kippur and Rosh Hashanah the estimates suggest that all the decrease in hours of works is due to time effects - although not statistically significant in the case of Rosh Hashanah, and no changes are due to differences across cohorts (in the case of Yom Kippur older cohorts tend to work longer hours, but the estimate is not statistically significant different to zero). These results are confirmed in the bottom panel when the sample is restricted to Florida and New York: all the decrease in hours of work during Yom Kippur and Rosh Hashanah are due to changes across time, although these estimates are measured imprecisely due to the smaller samples. These results support the hypothesis of an increase in the observance of jewish holidays by American workers, and importantly this increase occurs across all cohorts and is driven mostly by differences across time.

Next, columns (3), (4) and (5) show the estimates of changes in hours of work during Christian holidays. These results suggest important differences between Good Friday and the secularized holidays of Mardigras and Saint Patrick's. In the case of Good Friday the estimates suggest two reinforcing effects: in the one hand hours of work during this holiday increased across cohorts, where the youngest cohorts works on average

\footnotetext{
${ }^{18}$ One issue that must be addressed is that the estimate for Tu b'Shevat is positive and statistically significant different to zero. Why? Tu b'Shevat occurs in in February and it is in January and February when the variable Gapit is the lowest. Collapsing the 1000 placebo estimates in Figure 2 to month-year averages yields that 4 of the 10 lowest coefficient estimates averages belong to February $(1983,1985,1994$, and 2007), indeed among the lowest 20 coefficients estimated 8 include a February placebo - that is $40 \%$ within the lowest $2 \%$. That is when comparing Tu b' Shevat, and adding the month fixed effects, I am comparing February's with Tu b'Shevat with other Februaries that on average have very low Gapit.
} 
twenty minutes more than the earliest cohort; and hours of work increase as well across years, where workers work half an hour more on average during the later part of the sample than at the beggining of the sample. The bottom panel presents estimates when the sample is restricted to Alabama and Louisiana, and these two reinforcing effects increase in magnitude, 26 minutes more of work due to changes across cohorts and 96 minutes more of work due to changes across time. In contrast, when the analyzing changes in hours of work during Mardigras, changes across cohorts explain a significant part of the decrease in hours of work during this holiday: the youngest workers supply 20 minutes less of work than older workers, and this is partly offset by longer hours of work in the later period of the sample. Similarly, the estimates when the sample is restricted to Alabama and Louisiana show an increase in hours of work across cohorts, that is offset by a decrease in hours of work across cohorts (although none of these estimates are statistically significant different to zero). The estimates for Saint Patrick's also show a decrease of 10 minutes of work across cohorts, although this is not statistically significant, but this is reinforced with a decrease of 20 minutes across time which is statistically significant. As in Table 6, when the sample is restricted to New York and Massachusetts all the estimates are zero. These results confirm the hours of work have increased during Good Friday, and importantly these estimates reinforce each other across cohorts and across time, and together support a hypothesis of American workers (in particular those of Christian background) are becoming more secularized and less observant. In contrast, we see that estimates for Mardigras and Saint Patrick show a decrease in hours of work across cohorts for both holidays, and across time for Saint Patricks. Again these estimates suggest that although hours of work have increased during Good Friday, they decrease during Saint Patrick's and Mardigras. Note that, these later have become part of mainstream America, regardless of any worker's heritage or religion. These results support the hypothesis that American workers have not decreased their hours of work during religious holidays, rather they choose to work fewer hours during different holidays nowadays compared to thirty years ago.

\section{Summary}

In this paper I use religious holidays to understand the evolution in the schedule flexibility of American workers during the last thirty years. In addition, this revealed preference measure allows me to understand whether American workers have become more secularized or not. Using religious holidays as a natural experiment has the advantage that it yields three different sources of exogenous variation to answer these questions: variation from the survey design, variation due to the timing of the holiday and variation due to the nature of the holiday. My results suggests different results for christian holidays (including formerly Catholic holidays who now have become secularized), jewish holidays and muslim holidays. While comparing 
trends across across time, I observe a decrease in the frequency in the number of people taking time off from work in weeks that include Good Friday, yet I observe an increase in the number of people taking time off during Yom Kippur, Rosh Hashanah, Mardigras and Saint Patrick's Day. In addition, once that I control for differences across cohorts, I find that differences in frequency of workers taking time off during Yom Kippur and Rosh Hashanah are mostly common to all ages, while Mardigras and Saint Patrick's Day is driven mostly by differences across cohorts, particularly the youngest workers in the sample. These results suggests that the change in the frequency of people taking time off from work during religious holidays is not due to changes in workers' schedule flexibility, but due to changes in how we observe these holidays: a more secularized Christian America is less likely to observe Good Friday, and more likely to observe the secularized holidays of Mardigras or Saint Patrick's. Regarding the Jewish holidays of Rosh Hashanah and Yom Kippur, these results are supported in the Kiruv or the Baal Tashuva movement as well. Finally, I observe no change across time in the hours of work of American workers during Eid-al-Adha or the first day of Ramadan, this is perhaps because Islam has less members in the United States than Judaism or Christianity. In summary, as the labor market has changed in many dimensions during the last 30 years, the results in this paper suggests that schedule flexibility as measured with time off during religious holidays has changed very little during this time, and that while workers with a Christian background have become more secularized, such is not the case for workers from a jewish background. 


\section{References}

[1] Mark Aguiar and Erik Hurst. "Measuring leisure: The allocation of time over five decades". Quarterly Journal of Economics, 122(3):969-1006, 2007.

[2] Alberto Alesina, Edward Glaeser, and Bruce Sacerdote. "work and leisure in the u.s. and europe: Why so different?". NBER Macro Manual, 2005.

[3] David H. Autor, Lawrence F. Katz, and Melissa S. Kearney. The polarization of the u.s. labor market. The American Economic Review, 96(2):pp. 189-194, 2006.

[4] Ronen Bar-El, Teresa Garcia Muoz, Shoshana Neuman, and Yossi Tobol. "the evolution of secularization: cultural transmission, religion and fertility theory, simulations and evidence". Journal of Population Economics, 2012.

[5] Eli Berman, Laurence R. Iannaccone, and Guiseppe Ragusa. From empty pews to empty cradles: Fertility decline amon european catholics. Mimeo UCSD, 2007.

[6] Christopher R. Bollinger and Amitabh Chandra. Iatrogenic specification error: A cautionary tale of cleaning data. Journal of Labor Economics, 23(2):pp. 235-257, 2005.

[7] George J. Borjas. "The relationship between wages and weekly hours of work: The role of division bias". Journal of Human Resources, 15(3):409-423, 1980.

[8] George J. Borjas. Assimilation, changes in cohort quality, and the earnings of immigrants. Journal of Labor Economics, 3(4):pp. 463-489, 1985.

[9] George J. Borjas. Assimilation and changes in cohort quality revisited: What happened to immigrant earnings in the 1980s? Journal of Labor Economics, 13(2):pp. 201-245, 1995.

[10] Bureau of Labor Statistics. "Workers on flexible and shift schedules in May 2004, USDL 05-1198", 2005. Mimeo.

[11] David L. Clingingsmith, Asim Ijaz Khwaja, and Michael Kremer. The impact of the hajj: Religion and tolerance in islam's global gathering. Quarterly Journal of Economics, 124(3), 2009.

[12] Mary T. Coleman and John Pencavel. "Changes in work hours of male employees, 1940-1988". Industrial and Labor Relations Review, 46(2):262-283, 1993.

[13] Mary T. Coleman and John Pencavel. "Trends in market work behavior of women since 1940". Industrial and Labor Relations Review, 46(3):653-676, 1993. 
[14] Marie Conolly. "Here comes the rain again: Weather and the intertemporal substitution of leisure". Journal of Labor Economics, 26(1):73-100, 2008.

[15] Dora Costa. "The wage and the length of the work day: From the 1890s to 1991". Journal of Labor Economics, 18(1):156-181, 2000.

[16] Caitilin Knowles Myers Daniel C. Hamermesh and Mark L. Pocock. "Cues for timing and coordination: Latitude, letterman and longitude". Journal of Labor Economics, 26(2):223-246, 2008.

[17] Rajeev Dehejia, Thomas DeLeire, and Erzo F.P. Luttmer. Insuring consumption and happiness through religious organizations. Journal of Public Economics, 91(1,2):259 - 279, 2007.

[18] Richard B. Freeman. Who escapes? the relation of churchgoing and other background factors to the socioeconomic performance of black male youths from inner-city tracts. Richard B. Freeman and Harry J. Holzer (Eds.), The Black Youth Employment Crisis, page 353376, 1986.

[19] Jonathan H. Gruber. "religious market structure, religious participation, and outcomes: Is religion good for you?". Advances in Economic Analysis \& Policy, 5, 2005.

[20] Daniel C. Hamermesh. "12 million salary workers missing". Industrial and Labor Relations Review, 55(4):549-566, 2002.

[21] Laurence R. Iannaccone. Introduction to the economics of religion. Journal of Economic Literature, 36(3):pp. 1465-1495, 1998.

[22] Charlene Kalenkoski, David Ribar, and Leslie Stratton. The effect of family structure on parents child care time in the united states and the united kingdom. Review of Economics of the Household, 5:353-384, 2007.

[23] Peter J. Kuhn and Fernando A. Lozano. "The expanding workweek? understanding trends in long work hours among US men 1979-2006". Journal of Labor Economics, 26(2):311-344, 2008.

[24] Brent R. Moulton. An illustration of a pitfall in estimating effects of aggregate variables on micro units. Review of Economics and Statistics, 72(2):334-338, 1990.

[25] Peter Skogman-Thoursie. "Reporting sick: Are sporting events contagious". Journal of Applied Econometrics, 19(3):809-923, 2004. 


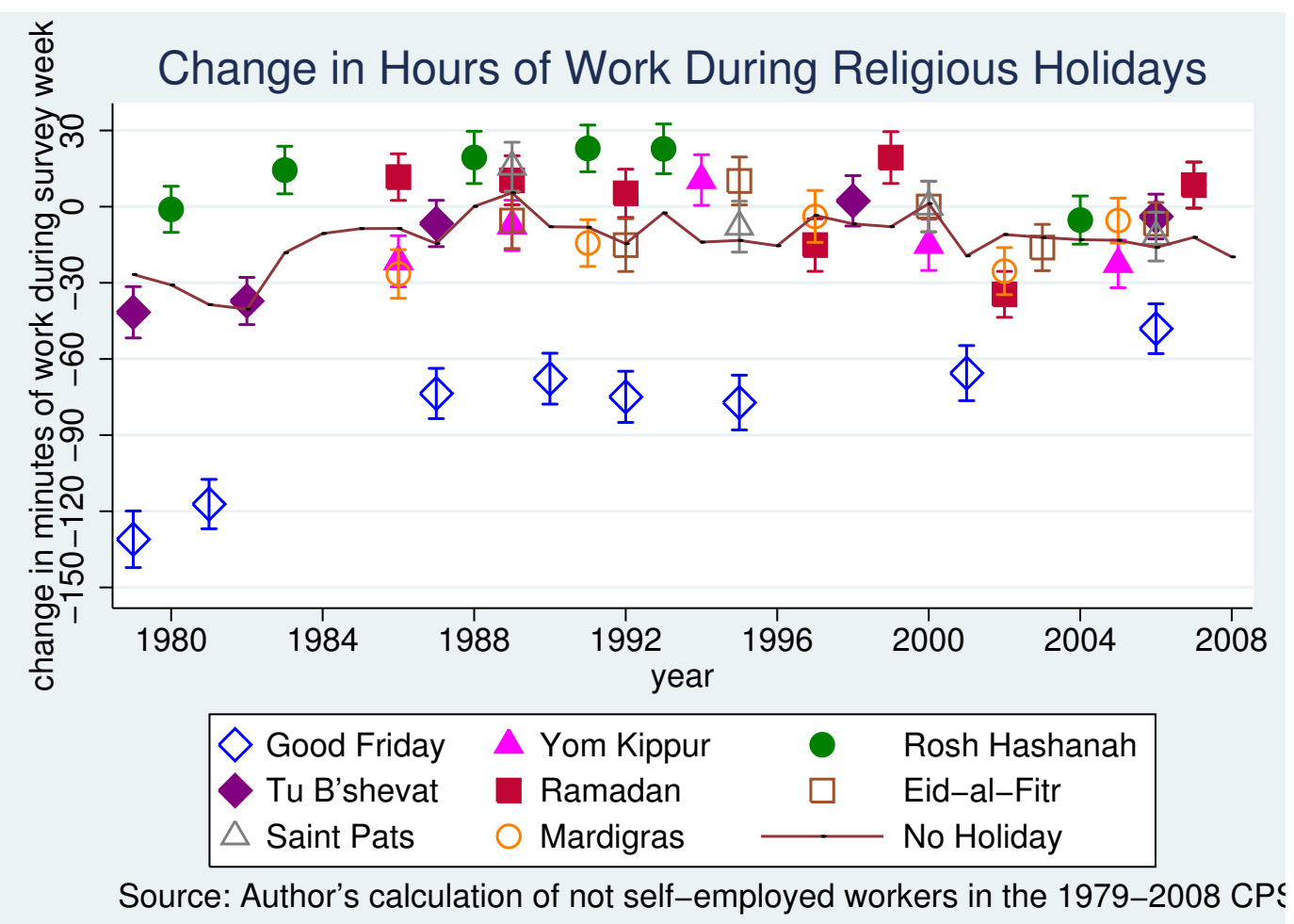




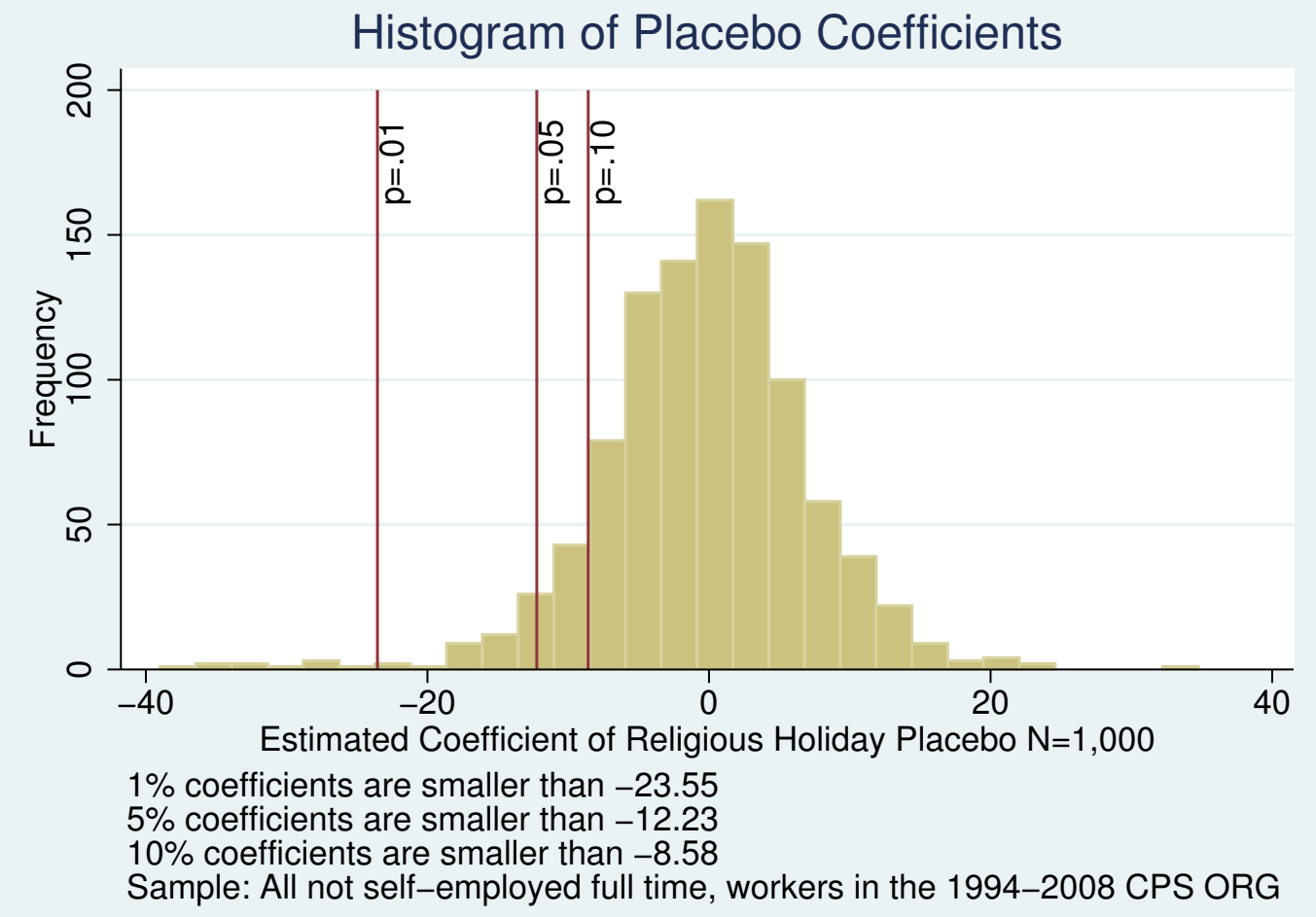


Table 2: Current Population Surveys and Religious Holidays

\begin{tabular}{|c|c|c|c|c|c|c|c|c|c|}
\hline \multirow[b]{2}{*}{ Month } & \multirow[b]{2}{*}{ Holiday } & \multicolumn{8}{|c|}{ CPS Rotation } \\
\hline & & 1 & 2 & 3 & 4 & 5 & 6 & 7 & 8 \\
\hline Jan 00 & & $\mathrm{O}$ & $\mathrm{N}$ & & & & & & \\
\hline Feb 00 & & $\mathrm{P}$ & $\mathrm{O}$ & $\mathrm{N}$ & & & & & \\
\hline Mar 00 & Saint Pats Fri 17th & $\mathrm{Q}$ & $\mathrm{P}$ & $\mathrm{O}$ & $\mathrm{N}$ & & & & \\
\hline Apr 00 & & $\mathrm{R}$ & $\mathrm{Q}$ & $\mathrm{P}$ & $\mathrm{O}$ & & & & \\
\hline May 00 & & $\mathrm{~S}$ & $\mathrm{R}$ & $\mathrm{Q}$ & $\mathrm{P}$ & & & & \\
\hline Jun 00 & & $\mathrm{~T}$ & $\mathrm{~S}$ & $\mathrm{R}$ & $\mathrm{Q}$ & & & & \\
\hline Jul 00 & & $\mathrm{U}$ & $\mathrm{T}$ & $\mathrm{S}$ & $\mathrm{R}$ & & & & \\
\hline Aug 00 & & $\mathrm{~V}$ & $\mathrm{U}$ & $\mathrm{T}$ & $\mathrm{S}$ & & & & \\
\hline Sep 00 & & $\mathrm{~W}$ & $\mathrm{~V}$ & $\mathrm{U}$ & $\mathrm{T}$ & & & & \\
\hline Oct 00 & Yom Kippur Mon 9th & $\mathrm{X}$ & W & $\mathrm{V}$ & $\mathrm{U}$ & & & & \\
\hline Nov 00 & & $\mathrm{Y}$ & $\mathrm{X}$ & $\mathrm{W}$ & $\mathrm{V}$ & & & & \\
\hline Dec 00 & & $\mathrm{Z}$ & $\mathrm{Y}$ & $\mathrm{X}$ & $\mathrm{W}$ & $\mathrm{N}$ & & & \\
\hline Jan 01 & & & $\mathrm{Z}$ & $\mathrm{Y}$ & $\mathrm{X}$ & $\mathrm{O}$ & $\mathrm{N}$ & & \\
\hline Feb 01 & & & & $\mathrm{Z}$ & $\mathrm{Y}$ & $\mathrm{P}$ & $\mathrm{O}$ & $\mathrm{N}$ & \\
\hline Mar 01 & Saint Pats Sat 17th & & & & Z & $\mathrm{Q}$ & $\mathrm{P}$ & $\mathrm{O}$ & $\mathrm{N}$ \\
\hline Apr 01 & & & & & & $\mathrm{R}$ & $\mathrm{Q}$ & $\mathrm{P}$ & $\mathrm{O}$ \\
\hline May 01 & & & & & & $\mathrm{~S}$ & $\mathrm{R}$ & $\mathrm{Q}$ & $\mathrm{P}$ \\
\hline Jun 01 & & & & & & $\mathrm{~T}$ & S & $\mathrm{R}$ & Q \\
\hline Jul 01 & & & & & & $\mathrm{U}$ & $\mathrm{T}$ & $\mathrm{S}$ & $\mathrm{R}$ \\
\hline Aug 01 & & & & & & $\mathrm{~V}$ & $\mathrm{U}$ & $\mathrm{T}$ & $\mathrm{S}$ \\
\hline Sep 01 & Yom Kippur Thurs 27th & & & & & $\mathrm{W}$ & $\mathrm{V}$ & $\mathrm{U}$ & $\mathrm{T}$ \\
\hline Oct 01 & & & & & & $\mathrm{X}$ & $\mathrm{W}$ & $\mathrm{V}$ & $\mathrm{U}$ \\
\hline Nov 01 & & & & & & Y & $\mathrm{X}$ & W & V \\
\hline Dec 01 & & & & & & Z & $\mathrm{Y}$ & $\mathrm{X}$ & $\mathrm{W}$ \\
\hline Jan 02 & & & & & & & $\mathrm{Z}$ & $\mathrm{Y}$ & $\mathrm{X}$ \\
\hline Feb 02 & & & & & & & & $\mathrm{Z}$ & $Y$ \\
\hline Mar 02 & & & & & & & & & $\mathrm{Z}$ \\
\hline
\end{tabular}


Table 3: Change in Minutes of Work during Religious Holidays

\begin{tabular}{lcccc}
\hline \hline & $(1)$ & $(2)$ & $(3)$ & $(4)$ \\
& Good Friday & Yom Kippur & Rosh Hashanah & Tu b'Shevat \\
\hline Change Minutes of Work & $-78.220^{*}$ & $-7.928^{*}$ & -1.231 & $10.333^{*}$ \\
& $(2.602)$ & $(2.893)$ & $(2.716)$ & $(2.834)$ \\
$\mathrm{r}^{2}$ & 0.010 & 0.010 & 0.010 & 0.010 \\
$\mathrm{~N}$ & $3,450,020$ & $3,450,020$ & $3,450,020$ & $3,450,020$ \\
\hline \multirow{4}{*}{ Change Minutes of Work } & $(5)$ & $(6)$ & $(7)$ & $(8)$ \\
& Ramadan & Eid-al-Ahda & Saint Patrick's Day & Mardigras \\
\hline & 2.719 & 3.905 & $-8.946^{*}$ & -0.618 \\
$\mathrm{r}^{2}$ & $(2.128)$ & $(2.429)$ & $(3.273)$ & $(2.840)$ \\
$\mathrm{N}$ & 0.010 & 0.010 & 0.010 & 0.010 \\
\hline \hline
\end{tabular}

Sample: All not self-employed full time workers in the CPS 1979-2008. Standard errors in parenthesis. Estimates include contros for age, age squared, age cube, age cuartic, education, salaried status, black, hispanic, marriage, month fixed effects, state fixed effects, year-occupation fixed effects. Robust standard errors are clustered at the Primary Sample Unit level. * Respresents statistically different to zero at $5 \%$ condence level. 
Table 4: Change in Minutes of Work during Religious Holidays Collapsed Data

\begin{tabular}{lcccc}
\hline \hline & $(1)$ & $(2)$ & $(3)$ & $(4)$ \\
& Good Friday & Yom Kippur & Rosh Hashanah & Tu b'Shevat \\
\hline Change Minutes of Work & $-79.288^{*}$ & $-7.203^{*}$ & -2.149 & $11.013^{*}$ \\
& $(3.918)$ & $(3.306)$ & $(3.675)$ & $(3.607)$ \\
$\mathrm{r}^{2}$ & 0.177 & 0.139 & 0.139 & 0.139 \\
$\mathrm{~N}$ & 18,105 & 18,105 & 18,105 & 18,105 \\
\hline \multirow{4}{*}{ Change Minutes of Work } & $(5)$ & $(6)$ & $(7)$ & $(8)$ \\
& Ramadan & Eid-al-Ahda & Saint Patrick's Day & Mardigras \\
\hline $\mathrm{r}^{2}$ & 2.971 & 3.641 & $-8.668^{*}$ & -0.951 \\
$\mathrm{~N}$ & $(2.675)$ & $(2.694)$ & $(4.217)$ & $(3.457)$ \\
\hline \hline
\end{tabular}

Sample: All not self-employed full time workers in the CPS 1979-2008. Data collapsed at the state-year-month level. Standard errors in parenthesis. Estimates include contros for age, age squared, age cube, age cuartic, education, salaried status, black, hispanic, marriage, month fixed effects, state fixed effects, year-occupation fixed effects. Robust standard errors are clustered at the Primary Sample Unit level. * Respresents statistically different to zero at $5 \%$ condence level. 
Table 5: Change Hours of Work During Religious Holidays

\begin{tabular}{lcccc}
\hline \hline & $(1)$ & $(2)$ & $(3)$ & $(4)$ \\
& Good Friday & Yom Kippur & Rosh Hashanah & Tu b'Shavot \\
\hline holidayX80 & $-102.191^{*}$ & -7.195 & 2.204 & 3.299 \\
& $(3.932)$ & $(4.406)$ & $(3.756)$ & $(3.571)$ \\
holidayX90 & $-76.445^{*}$ & -1.012 & 3.127 & $16.647^{*}$ \\
& $(3.757)$ & $(6.258)$ & $(4.408)$ & $(6.187)$ \\
holidayX00 & $-56.082^{*}$ & $-11.709^{*}$ & $-9.503^{*}$ & $19.952^{*}$ \\
& $(4.475)$ & $(4.449)$ & $(4.484)$ & $(5.098)$ \\
$\mathrm{r}^{2}$ & 0.012 & 0.011 & 0.011 & 0.011 \\
$\mathrm{~N}$ & $3,425,020$ & $3,425,020$ & $3,425,020$ & $3,425,020$ \\
\hline & $(5)$ & $(6)$ & $(7)$ & $(8)$ \\
& Ramadan & Eid-al-Adha & Saint Patrick's & Mardigras \\
\hline holidayX80 & 5.907 & 6.086 & -2.572 & $-18.351^{*}$ \\
& $(3.414)$ & $(6.466)$ & $(5.714)$ & $(5.872)$ \\
holidayX90 & 3.777 & 6.612 & -8.136 & 3.037 \\
& $(3.569)$ & $(4.338)$ & $(6.312)$ & $(4.350)$ \\
holidayX00 & -2.314 & 1.634 & $-12.437^{*}$ & 2.630 \\
& $(4.109)$ & $(3.271)$ & $(4.545)$ & $(4.057)$ \\
$\mathrm{r}^{2}$ & 0.011 & 0.011 & 0.011 & 0.011 \\
$\mathrm{~N}$ & $3,425,020$ & $3,425,020$ & $3,425,020$ & $3,425,020$ \\
\hline \hline
\end{tabular}

Sample: All not self-employed full time workers in the CPS 1979-2008. Standard errors in parenthesis. Estimates include contros for age, age squared, age cube, age cuartic, education, salaried status, black, hispanic, marriage, month fixed effects, state fixed effects, year-occupation fixed effects. Robust standard errors are clustered at the Primary Sample Unit level. ${ }^{*}$ Respresents statistically different to zero at $5 \%$ condence level. 
Table 6: Predicted Change in Hours of Work - Selected Subsamples

\begin{tabular}{|c|c|c|c|c|c|}
\hline & $\begin{array}{c}\text { (1) } \\
\text { Yom Kippur }\end{array}$ & $\begin{array}{c}(2) \\
\text { Bosh Hashanah }\end{array}$ & $\begin{array}{c}(3) \\
\text { Gond Fridav }\end{array}$ & $\begin{array}{c}(4) \\
\text { Mardigras }\end{array}$ & $\begin{array}{c}(5) \\
\text { Saint Patrick's }\end{array}$ \\
\hline & \multicolumn{5}{|c|}{ (a) Average Estimates } \\
\hline holiday & $\begin{array}{c}-14.38^{*} \\
(6.67)\end{array}$ & $\begin{array}{l}-3.28 \\
(6.47)\end{array}$ & $\begin{array}{c}-94.69^{*} \\
(16.10)\end{array}$ & $\begin{array}{c}-79.00^{*} \\
(18.81)\end{array}$ & $\begin{array}{l}-2.25 \\
(9.41)\end{array}$ \\
\hline Sample & \multicolumn{2}{|c|}{ NY, FL } & \multicolumn{2}{|c|}{$\mathrm{LA}, \mathrm{AL}$} & NY, MA \\
\hline $\mathrm{r}^{2}$ & 0.01 & 0.01 & 0.03 & 0.03 & 0.02 \\
\hline $\mathrm{N}$ & 483,432 & 483,432 & 81,295 & 81,295 & 305,641 \\
\hline & \multicolumn{5}{|c|}{ (b) Estimates Across Time } \\
\hline holidayX80 & $\begin{array}{l}-16.71 \\
(10.15)\end{array}$ & $\begin{array}{l}8.68 \\
(9.04)\end{array}$ & $\begin{array}{c}-136.17^{*} \\
(25.20)\end{array}$ & $\begin{array}{l}-41.94 \\
(41.04)\end{array}$ & $\begin{array}{l}-10.59 \\
(18.56)\end{array}$ \\
\hline holidayX90 & $\begin{array}{c}8.57 \\
(11.75)\end{array}$ & $\begin{array}{c}4.48 \\
(10.08)\end{array}$ & $\begin{array}{c}-109.74^{*} \\
(22.06)\end{array}$ & $\begin{array}{l}-95.34^{*} \\
(30.02)\end{array}$ & $\begin{array}{c}9.77 \\
(16.60)\end{array}$ \\
\hline holidayX00 & $\begin{array}{c}-24.39^{*} \\
(11.29)\end{array}$ & $\begin{array}{c}-22.66^{*} \\
(10.93)\end{array}$ & $\begin{array}{l}-18.59 \\
(26.50)\end{array}$ & $\begin{array}{c}-80.36^{*} \\
(26.14)\end{array}$ & $\begin{array}{c}-4.44 \\
(13.25)\end{array}$ \\
\hline Sample & \multicolumn{2}{|c|}{ NY, FL } & \multicolumn{2}{|c|}{ LA, AL } & NY, MA \\
\hline$r^{2}$ & 0.01 & 0.01 & 0.02 & 0.02 & 0.02 \\
\hline $\mathrm{N}$ & 483,432 & 483,432 & 81,295 & 81,295 & 305,641 \\
\hline
\end{tabular}

Sample: All not self-employed full time workers living in the restricted states in the CPS 1979-2008. Standard errors in parenthesis. Estimates include contros for age, age squared, age cube, age cuartic, education, salaried status, black, hispanic, marriage, month fixed effects, state fixed effects, year-occupation fixed effects. Robust standard errors are clustered at the Primary Sample Unit level. * Respresents statistically different to zero at $5 \%$ condence level. 
Table 7: Change Hours of Work During Religious Holidays, by(Cohort Year)

\begin{tabular}{lccccc}
\hline \hline & $(1)$ & $(2)$ & $(3)$ & $(4)$ & $(5)$ \\
& Yom Kippur & Rosh Hashanah & Good Friday & Mardigras & Saint Patrick's \\
\hline HolidayXc1 & 0.83 & 4.16 & $-108.82^{*}$ & -7.80 & $17.17^{*}$ \\
& $(5.22)$ & $(4.03)$ & $(4.27)$ & $(6.39)$ & $(6.50)$ \\
HolidayXc2 & 9.68 & 1.78 & $-96.59^{*}$ & -11.37 & $13.63^{*}$ \\
& $(5.56)$ & $(4.91)$ & $(4.97)$ & $(6.79)$ & $(6.89)$ \\
HolidayXc3 & 11.47 & -2.38 & $-87.12^{*}$ & $-20.52^{*}$ & 7.62 \\
& $(6.80)$ & $(6.67)$ & $(6.52)$ & $(7.50)$ & $(7.81)$ \\
HolidayX90 & -14.57 & 6.45 & $24.23^{*}$ & $20.06^{*}$ & $-25.29^{*}$ \\
& $(7.47)$ & $(5.46)$ & $(5.15)$ & $(7.05)$ & $(8.13)$ \\
HolidayX00 & $-13.13^{*}$ & -6.14 & $33.67^{*}$ & $19.15^{*}$ & $-17.95^{*}$ \\
& $(6.47)$ & $(6.56)$ & $(6.40)$ & $(7.21)$ & $(7.48)$ \\
$\mathrm{r}^{2}$ & 0.01 & 0.01 & 0.01 & 0.01 & 0.01 \\
$\mathrm{~N}$ & $3,450,020$ & $3,450,020$ & $3,450,020$ & $3,450,020$ & $3,450,020$ \\
\hline
\end{tabular}

\section{Selected Subsamples}
(6)
(7)
(8)
(9)
(10)

Yom Kippur Rosh Hashanah Good Friday Mardigras Saint Patrick's

\begin{tabular}{lccccc}
\hline HolidayXc1 & -7.16 & 12.81 & $-138.22^{*}$ & -70.81 & -0.23 \\
& $(11.33)$ & $(9.13)$ & $(25.89)$ & $(45.07)$ & $(17.54)$ \\
HolidayXc2 & -3.51 & -2.21 & $-114.39^{*}$ & -30.69 & 10.11 \\
& $(13.26)$ & $(13.12)$ & $(30.74)$ & $(47.37)$ & $(16.37)$ \\
HolidayXc3 & 4.11 & 2.39 & $-112.83^{*}$ & -12.12 & -1.70 \\
& $(15.45)$ & $(16.07)$ & $(38.72)$ & $(55.98)$ & $(16.82)$ \\
HolidayX90 & 0.99 & 1.00 & 23.52 & -58.39 & 8.51 \\
& $(15.54)$ & $(13.19)$ & $(30.98)$ & $(50.17)$ & $(19.21)$ \\
HolidayX00 & -12.63 & -25.48 & $96.17^{*}$ & -60.42 & 0.34 \\
& $(15.53)$ & $(16.97)$ & $(38.63)$ & $(50.98)$ & $(17.18)$ \\
Sample & & $\mathrm{NY}, \mathrm{FL}$ & $\mathrm{LA}, \mathrm{AL}$ & $\mathrm{NY}, \mathrm{MA}$ \\
$\mathrm{r}^{2}$ & 0.01 & 0.01 & 0.02 & 0.02 & 0.01 \\
$\mathrm{~N}$ & 483,432 & 483,432 & 81,295 & 81,295 & 445,125 \\
\hline \hline
\end{tabular}

Sample: All not self-employed full time workers living in the restricted states in the CPS 1979-2008. Standard errors in parenthesis. Estimates include contros for age, age squared, age cube, age cuartic, education, salaried status, black, hispanic, marriage, month fixed effects, state fixed effects, year-occupation fixed effects. Robust standard errors are clustered at the Primary Sample Unit level. * Respresents statistically different to zero at $5 \%$ condence level. 